\title{
Download
}

UDC 911.3 https://doi.org/10.17721/2308-135X.2021.61.12-12

Mashika Hanna Vasylivna, Doctor of Geographical Sciences, Associate Professor Uzhhorod National University, Uzhhorod, Ukraine,

e-mail: mashika.g.v.@i.ua

Nych Tetyana Vasylivna, Candidate of Geographical Sciences Taras Shevchenko National University of Kyiv, Kyiv, Ukraine, e-mail: tatyana2510@ukr.net

\section{SOCIO-ECONOMIC VECTORS OF TOURIST SPHERE DEVELOPMENT OF THE CARPATHIAN REGION IN THE CONDITION OF THE COVID-19 PANDEMIC}

The aim of the article is to analyze the existing approaches to understanding the way out of the crisis in the Carpathian region caused by the COVID-19 pandemic, to determine the positioning of the tourism sector and its position relative to other natural and geographical areas, highlighting its main functions and problems. Development of directions and prospects of development of the tourist sphere of the Carpathian region.

Method. The study was conducted on the basis of the analysis of available literature sources on this topic and the application of a spherical approach to the analysis of the positioning of the tourist sphere of the Carpathian region and the definition of its components. Existing domestic and foreign literary sources and the ratio of these concepts within this literature on COVID-19 are studied. 
Results. Theoretical and methodological problems of comparing concepts related to the tourism sector of the Carpathian region, its elements and their interchangeability and interconnectedness during the COVID-19 pandemic have been studied. The scheme of exit of the tourist sphere and its components from the crisis is offered. Based on the spherical approach, a model of the tourism sector in the post-COVID-19 period is proposed, which we consider as a model formed within the model territory - the Carpathian region, taking into account the following elements: socio-demographic, socio-spiritual, political-economic, naturalecological, information and technical. Within each element that has a significant impact on the tourism sector, there are three main vectors that have the greatest impact on the tourism sector.

Scientific novelty. The need for this study is due to the fact that despite the effects and to date it is not possible to fully assess the effects and effects of COVID-19. To date, there are no clear criteria that should bring the tourism sector of the Carpathian region to the appropriate level, this is what led to the implementation of this study. The article considers and identifies systemic problems related to Covid- 19 , which create negative trends in the use of tourist and recreational potential of the Carpathian region.

Practical significance. Based on modeling and analysis, the main areas that affect the tourism sector as such and to what extent are identified, the areas of greatest influence and sectors of influence within the Carpathian region are identified. The functions of the tourism sector and the main factors that affect its development and transformation, as well as what measures need to be implemented to improve the situation in connection with Covid-19. The directions in which the most expedient application of adjustment of actions for increase of tourist potential of the Carpathian region is established are established. The results of the study are designed for regional government agencies to plan a program for the development of tourism in the context of the development of the United Territorial Communities. The geographical features of the tourism sector are highlighted, which need to be paid the most attention when analyzing the exit of the tourism sector from the crisis caused by COVID-19.

Key words: tourism sphere, tourism, COVID-19, pandemic, Carpathian region.

References

1. Zakarpats'ka oblast'. Kolekty'vni zasoby' rozmishhuvannya(yury'dy'chni osoby', vidokremleni pidrozdily' yury'dy'chny'x osib) [Elektronny'j resurs]. Rezhy'm dostupu:

http://www.uz.ukrstat.gov.ua/statinfo/turism/zasob_rozm.pdf 
2. Zakarpats'ka oblast'. Kil'kist' tury'stiv, obslugovany'x turoperatoramy' ta turagentamy', za vy'damy' tury'zmu [Elektronny'j resurs]. Rezhy'm dostupu:http://www.uz.ukrstat.gov.ua/statinfo/turism/tur_potoki.pdf

3. Zakarpats'ka oblast'. Dy'tyachi zaklady' ozdorovlennya ta vidpochy'nku, yaki pracyuvaly' vlitku[Elektronny'j resurs]. Rezhy'm dostupu:

http://www.uz.ukrstat.gov.ua/statinfo/turism/zakl_ozdor.pdf

4. Zakarpat'ska oblast' Sanatorno-kurortni ta ozdorovchi zaklady'[Elektronny'j resurs]. Rezhy'm dostupu: http://www.uz.ukrstat.gov.ua/statinfo/turism/sanatorij.pdf

5. Zeleny'j tury'zm»-2020: inodi - yak variant dlya «karanty'nnogo» usamitnennya[Elektronny'j resurs]. Rezhy'm dostupu:

https://www.ukrinform.ua/rubric-tourism/3058062-zelenij-turizm2020-inodi-ak-variant-dla-karanti nnogo-usamitnenna.html

6. Ivano-Frankivs'ka oblast'. Sanatorno-kurortni ta ozdorovchi zaklady'[Elektronny'j resurs].

Rezhy'm dostupu: http://www.ifstat.gov.ua/EX_IN/T3.HTM

7. Ivano-Frankivs'ka oblast'. Kolekty'vni zasoby' rozmishhuvannya[Elektronny'j resurs]. Rezhy'm dostupu: http://www.ifstat.gov.ua/EX_IN/T4.HTM

8. Ivano-Frankivs'ka oblast'. Kil'kist' tury'stiv, obslugovany'x turoperatoramy' ta turagentamy', za vy'damy' tury'zmu[Elektronny'j resurs]. Rezhy'm dostupu:

http://www.ifstat.gov.ua/EX_IN/T1.HTM

9. Ivano-Frankivs'ka oblast'. Dy'tyachi zaklady' ozdorovlennya ta vidpochy'nku, yaki pracyuvaly' vlitku[Elektronny'j resurs]. Rezhy'm dostupu: http://www.ifstat.gov.ua/EX_IN/T6.HTM 
10. L'vivs'ka oblast'. Kil'kist' tury'stiv, obslugovany'x turoperatoramy' ta turagentamy', za vy'damy' tury'zmu[Elektronny'j resurs]. Rezhy'm dostupu:

http://www.Iv.ukrstat.gov.ua/ukr/si/year/2018/t249918_1.pdf

11. L'vivs'ka oblast'. Sanatorno-kurortni ta ozdorovchi zaklady' [Elektronny'j resurs]. Rezhy'm dostupu: http://www.Iv.ukrstat.gov.ua/ukr/si/year/2011/t249911_3.pdf

12. L'vivs'ka oblast'. Kolekty'vni zasoby' rozmishhuvannya [Elektronny'j resurs]. Rezhy'm dostupu: http://www.Iv.ukrstat.gov.ua/ukr/si/year/2019/t249919_4.pdf

13. L'vivs'ka oblast'. Dy'tyachi zaklady' ozdorovlennya ta vidpochy'nku, yaki pracyuvaly' vlitku[Elektronny'j resurs]. Rezhy'm dostupu:

http://www.Iv.ukrstat.gov.ua/ukr/si/year/2012/t249912_5.pdf

14. Kolekty'vni zasoby' rozmishhuvannya Chernivecz'koyi oblasti [Elektronny'j resurs]. Rezhy'm dostupu:

https://www.google.com/url?sa=t\&rct=j\&q=\&esrc=s\&source=web\&cd=\&cad=rja\&uact=8\&ved=2 ahUKEwjVt622_pbvAhVmxoUKHck2CSQQFjACegQIAhAD\&url=https\%3A\%2F\%2Fwww.0372. ua\%2Fnews\%2F2469583\%2Fskilki-kolektivnih-zasobiv-rozmisuvanna-funkcionuvalo-na-bukovi ni-u-2018-roci\&usg=AOvVaw1GdNUEqevLfzRcV9uC59bc

15. Mexanizmy' zabezpechennya efekty'vnogo vy'kory'stannya tury'sty'chno-rekreacijnogo potencialu girs'ky'x rajoniv zaxidny'x regioniv Ukrayiny'". Anality'chna zapy'ska [Elektronny'j resurs]. Rezhy'm dostupu: https://niss.gov.ua/en/node/1177.

16. Proekt programy' dy'stancijnoyi vseukrayins'koyi naukovo-prakty'chnoyi konferenciyi «Ukrayins'ky'j tury'zm v umovax korona ta post korona virusnogo periodu: anty'kry'zovi scenariyi, mizhnarodny'j dosvidu, krashhi prakty'ky'» [Elektronny'j resurs]. Rezhy'm dostupu: https://geo.knu.ua/images/kafedra/geography_of_Ukraine/KonferenzKK_Programa.pdf

17. Pandemiya COVID-19 ta yiyi naslidky' u sferi tury'zmu v Ukrayini [Elektronny'j resurs]. Rezhy'm dostupu: http://www.ntoukraine.org/assets/files/EBRD-COVID19-Report-UKR.pdf 
18. Chernivecz'ka oblast'. Sanatorno-kurortni ta ozdorovchi zaklady' [Elektronny'j resurs]. Rezhy'm dostupu: http://www.cv.ukrstat.gov.ua/statinf/tur/san.htm

19. Chernivecz'ka oblast'. Kolekty'vni zasoby' rozmishhuvannya [Elektronny'j resurs]. Rezhy'm dostupu: http://www.cv.ukrstat.gov.ua/statinf/tur/kolek.htm

20. Chernivecz'ka oblast'. Kil'kist' tury'stiv, obslugovany'x turoperatoramy' ta turagentamy', za vy'damy' tury'zmu [Elektronny'j resurs]. Rezhy'm dostupu:http://www.cv.ukrstat.gov.ua/statinf/tur/trs.htm

21. Chernivecz'ka oblast'. Dy'tyachi zaklady' ozdorovlennya ta vidpochy'nku, yaki pracyuvaly' vlitku [Elektronny'j resurs]. Rezhy'm dostupu: http://www.cv.ukrstat.gov.ua/statinf/tur/dit.htm

22. Tur_dil_18.[ls [Elektronny'j resurs]. Rezhy'm dostupu:

https://www.google.com/url?sa $=$ \& $\& \mathrm{rct}=j \& q=\&$ esrc=s\&source $=$ web\&cd $=\& \mathrm{cad}=\mathrm{rja} \&$ uact $=8 \& v e d=2$ ahUKEwidhcfutMTVAhVMtIsKHS0GDA0QFjACegQIAxAD\&url=https\%3A\%2F\%2Fukrstat.org\% 2Fuk\%2Foperativ\%2Foperativ2019\%2Ftyr\%2Ftyr_dil\%2Ftur_dil_18.xls\&usg=AOvVaw0683PQ M6rAgICbzoUq2IPO 